\title{
Promises for cluster progression: Russian automotive market outlook
}

\author{
Elena Korostyshevskaya ${ }^{1,},{ }^{,}$, Anatoliy Chudakov $^{1}$ \\ ${ }^{1}$ Saint Petersburg State University, 7/9 Universitetskaya nab., Saint Petersburg, 199034, Russia
}

\begin{abstract}
Purpose of this article is to define the ability of Russian institutions to act as agents of change and innovation. Growing multi local economic activity stimulates innovative enterprises for cooperation with stakeholders. Usually, it means consumers, suppliers, authorities and government involvement in change processes. If achievement of interests balance is clear and transparent for all stakeholders, they will be change agents. Modern experience in streamlining social and economic relations between stakeholders focuses on the development of functional institutions that can act as agents of change. Forms of organization of such institutions can be clusters, technology parks, holdings, management companies, joint-stock companies, state-owned companies, manufacturers' associations, marketing cooperatives, and professional communities. Research methods are statistics index analysis and network analysis. Working with these research methods, World Bank InputOutput Database, Federal Custom data, Rosstat data and law searching system we prove impossibility of full-fledged cluster policy implementation. Finally we prove that present Russian institutes are complacent and require more transparency. Consequently, cluster progression needs for common institutional space, supporting clear and transparent transactions between stakeholders, regardless of their location and technologies used.
\end{abstract}

\section{Cluster progression: theoretical review}

Currently, global value chains being an independent research area are a part of the study in a regional innovative economy. Today, it is a dominant non-competitive organizational form for international business and international markets. However, for the most national economies, the strategic activity of international business comprises the search of solutions focused on the operating activity adaptation to local conditions and markets [1]. Let consider relation types appeared between vendors and consumers in global value chains.

- Market chain. It comprises relatively simple relations. Product specifications are easily transmitted; vendors may manufacture products with a minimum customer

* Corresponding author: e.korostyshevskaya@ spbu.ru 
contribution. The exchange between companies almost does not need official cooperation between players while the cost of the transfer to new partners is low both for manufacturers and buyers. Price is the central management mechanism [2].

- Modular chain. Modular management appears when complicated relations are relatively easy to standardize. As a rule, vendors in modular chains fabricate products according to customer specifications and bear sole responsibility for technological processes using multi-purpose equipment; they have a fair amount of clients. This allows reducing costs for production changeover and limits investments specific for relations, even a buyer and a vendor may have very complicated relations. Information technologies and data interchange standards are keys for the module management functioning [3].

- Attitudinal chain. This chain occurs, when buyers and sellers rely on complicated information that is not easy to convey or study. It results in frequent interactions and knowledge sharing between parties. These relations require trust and generate mutual confidence, which is governed by reputation, social and spatial vicinity, family, ethnic, cultural ties, etc. Despite the mutual dependence, leading companies are still able to control vendors to a certain extent. Most likely, manufacturers will supply differentiated products in attitudinal chains based on quality, geographic origin, and other unique characteristics. This kind of chains requires time for establishing; that's why, costs and difficulties necessary to get new partner are high as a rule [4].

- Invasive chain. Within these chains, small vendors depend on one or several buyers having much power. These networks feature the high monitoring and control degree performed by a leading company. Strong information asymmetry in relations forces vendors to establish connection with its own buyer under conditions, which are often set by this particular buyer and are often specific for it resulting in close ties and high changeover costs for both parties. Since the core competence of leading companies is usually outside the production, the assistance to their suppliers in their upgrading does not touch this primary competence but benefits the leading company by improving efficiency of its supply chains Ethics is important in relations to ensure fair relation to vendors and fair share of market price [5].

- Hierarchical chain. This kind of chains feature vertical integration and management control in leading companies that design and fabricate products themselves. It usually occurs, when product specifications are not subject to standardization; products are complex; or it is impossible to find highly qualified vendors. Although such vertical integration is less common than in the past, it remains an important specific feature of the global economy.

- Management form may change as the industry develops, while management patterns in the industry may vary from one stage of chain level to another. Besides, a recent study has shown that many global value chains feature multiple and interacting management structures [6].

Being a part of the research field in the regional innovating economy, clusters today are an independent trend. Clusters are the main supplier of new products at global markets. However, cluster functions cover not only the operating efficiency increase for international business but the human capital development for a national economy [7].

The national innovative system concept is among the earliest studies in this field. Researches describe a national innovative system (NIS) as a network of institutions in public (state) and private sector, which initiate, import, modify and disseminate new technologies by their interaction. In later studies, a NIS is described as a cluster of institutions and practices, which define a local ability of the industry or a government to produce and apply innovations worldwide. Institutions in this context mean any communities organized by a 
formal and/or informal way- from universities to investors and consumer groups [8].

The strong tie between $R \& D$ projects and the institutional environment is a core driver for the implementation of technical innovations. Institutions have a low flexibility and adaptivity level; therefore, they should have an additional selective function. Thereby, external environment gains the possibility to assess the technology implementation at the expense of the competition between manufacturers and the market demand [9].

Historically-formed economy structure comprising relations in the industry and institutionally-organizational structures (including R\&D works) defines significantly development of the innovation system. Educational processes, which promote innovation dissemination, appear as the interaction result between manufacturers, and between knowledge producers and consumers. Abilities to work out fundamentally new technologies gradually increase. Innovation processes become active based on strengthening the interaction between networks of the institutions participated in the whole system [10].

According to empirical analysis for the countries with mature markets, private sector is the central agent in this interaction being the most flexible and adaptive institution. It is able to implement its competitive advantages most efficiently. At the same time, this results in the growth of traditionally strong sectors within the whole country and the delay in the less developed economy ones as before. Complementarity is observed between university researches, collaborative $R \& D$ works between universities and entrepreneurs, who are related with cooperation strategies between institutes and the governmental industrial policy programs targeted at a strictly defined specialization [11]. On the other hand, the government pursuing a proactive economic policy may be the main driver for the interaction between institutions [12].

Interaction in the triple helix concept occurs between universities, business entities and the government in the society based on the knowledge. It is impossible to consider innovations from the sole viewpoint of creating a particular product. The triple helix is a basis for establishing new institutions and new organizational forms, which would be able to unite all participants of the innovation process.

The author of the model notes that a university plays a more significant role in the knowledge-based society than in the industrial one. Talented young people (students) are the unique competitive advantage of the university, who enter educational institutions with innovative ideas and scientific hypotheses. Upon graduation, they can immediately start implementing their scientific hypotheses and projects working for society. Universities build relationships with the private sector and a government as an equal institutional partner [13].

Etzkowitz emphasizes that all three institutional spheres - universities, the private sector, and the government - execute their traditional missions but start playing new role by performing duties of other institutional spheres. For example, universities involved in the education and research studies play an active role in economic development, i.e. perform the traditional business function. Today, this already happens through establishing knowledgeintensive small innovative entities at educational institutions. Founders of these companies came from the academic environment and managed to put theoretical knowledge into practice. Private sector regularly improves staff skills. The government actively funds commercial institutions, knowledge-intensive entrepreneurship and universities to develop the ability to create a new innovative business. In other words, it carries out a venture (entrepreneurial) activity [14]. Where institutional spheres partially overlap the functions of each other, people meet and generate new ideas. Civil society institutions contribute to their appearance and implementation [15]. 


\section{Research methods}

We used a multidimensional data model to search for modern trade flows at the intersectional interregional level with a "supplier to consumer" correlation depth of Tier 2. This model consists of oriented graph D (1) and World Bank "Input-Output Database"

$$
\boldsymbol{D}=(\boldsymbol{V}, \boldsymbol{E})
$$

Elements of set $\boldsymbol{V}$ are industries and countries, ordered vertices' pairs $\boldsymbol{u}, \boldsymbol{v} \in \boldsymbol{V}$ of set $\boldsymbol{E}$ are trade flows.

Using equation (2), we compare dynamics and year-to-year consumption of automotive industry intermediate production and automobiles from 2005 up to 2016

$$
\boldsymbol{i}=\boldsymbol{p}_{\boldsymbol{t}} / \boldsymbol{p}_{\boldsymbol{t}-1}
$$

In this equation $\boldsymbol{i}$ - year-to-year increase, $\boldsymbol{p}_{\boldsymbol{t}}$ - learned indicator in the current year, $\boldsymbol{p}_{\boldsymbol{t}-\mathbf{1}}$ - learned indicator in the previous year.

\section{Russian automotive market outlook: main results}

Decree of the Government of the Russian Federation as of March 29, 2005, Ref. No. 166 "On Amendments Being Made in the Customs Tariff of the Russian Federation Regarding Vehicle Components Imported for Industrial Assembly" became a modern reference point for the automotive industry development.

Under the term of the decree, preferences are granted to foreign and Russian investors (3 to $5 \%$ rate) to import Tier- 1 products and components for the car industry subject to the further localization of production facilities within the Russian Federation. Simultaneously, the customs duty rate for the finished car import increased up to 30 to $35 \%$. Segmented customs preferences of the RF Government were a significant argument for attracting foreign direct investments. It became more profitable to create added value by manufacturing in Russia since the final sales price of a finished car was higher several times.

Since 2005, the RF Government reinforced the industrial assembly regime by stimulating sales for the automotive facilities localized in the Russian Federation. For example, establishing a preferential regime in the system of governmental and municipal orders upon attaining a certain localization level; sponsoring purchases of gas-engine vehicles; sponsoring car credit purchases within programs "The First Car" and "A Family Car"; sponsoring the part of the leasing cost within programs "Russian Tow Car", "Russian Farmer", "Own Business" [18]. However, low rates of the real GDP growth and the drop of the population real income force automakers to reduce car production or optimize it.

The Russian Federation became a WTO member since 2011. Application of the "industrial assembly" regime contradicts WTO agreements regarding the Agreement on Trade-Related Investment Measures (TRIMs), the Agreement on Subsidies and Countervailing Measures (SSCM) and the General Agreement on Tariffs and Trade (GATT). Customs preferences set by the Government since 2005 to conclude "industrial assembly" investment agreements will void since July 1, 2018, including EAEU member states [19]. In this context, the risk significantly increases regarding earnings dilution of investment return in the motor vehicle production. Production of car components in the RF within the implementation of localization rate by investment agreements will depend on the ability of car builders to make value offers. Defrayment probability increases due to the import of unsold demand [20, 21, 22, 23],. (Figs. 1-3.). 


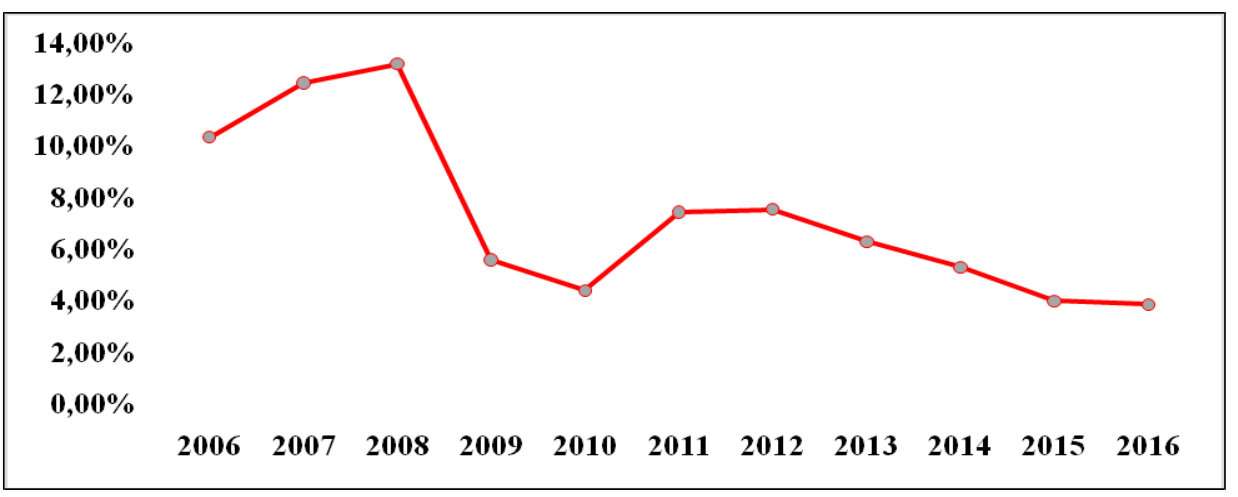

Fig.1. Import of the ultimate use products.

Source: Compiled by the data of: Federal Customs Service, Rosstat

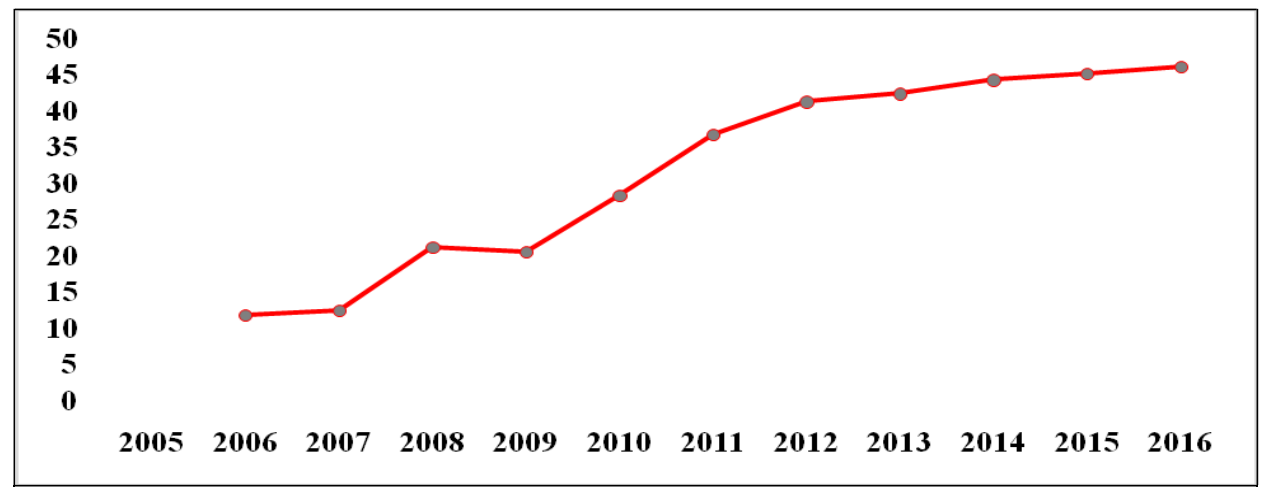

Fig.2. Import of the intermediate use products.

Source: Compiled by the data of: Federal Customs Service, Rosstat

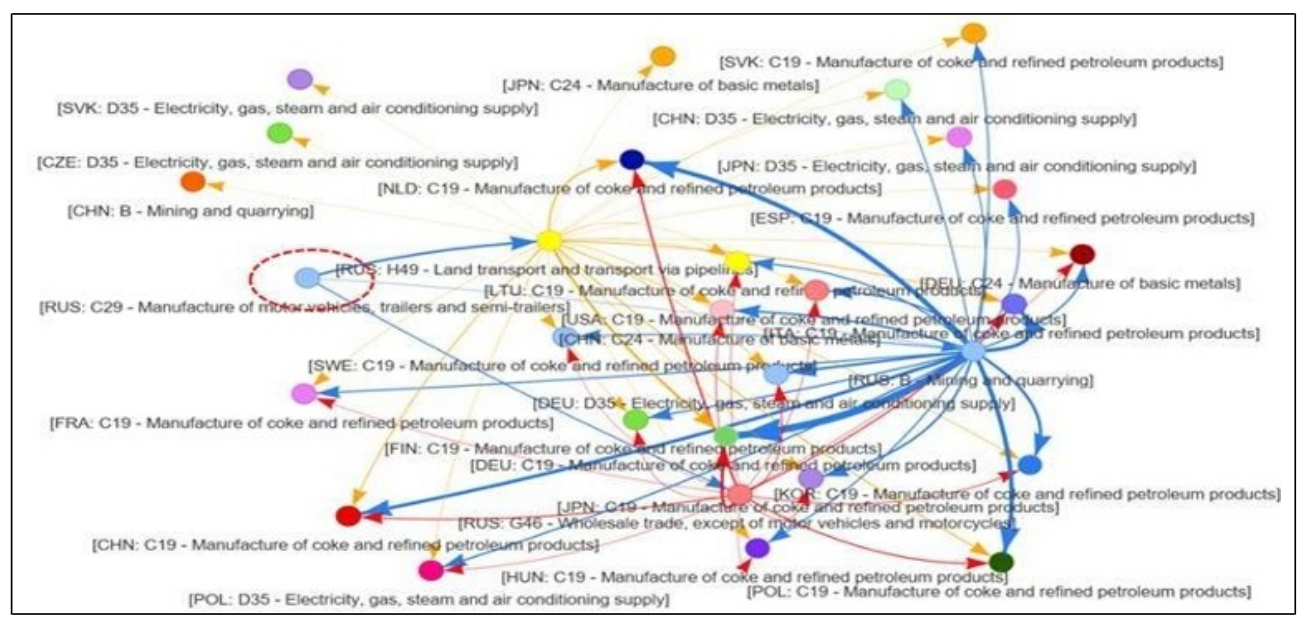

Fig.3. Basic motor vehicle consumers in the Russian market.

Source: authors 
Tools for drawing and stimulating innovation mainly at the expense of consumer demand have exhausted themselves. The production output increase depends for national companies upon the ability to fabricate innovative products, which is possible to develop by subcontracting expansion in the automotive and related industries. Implementation of these initiatives is expedient only through the involvement of the main stakeholders: federal, regional and municipal authorities; key vendors, consumers; scientific and educational institutions; sectoral venture capital [22]. (Fig. 4).

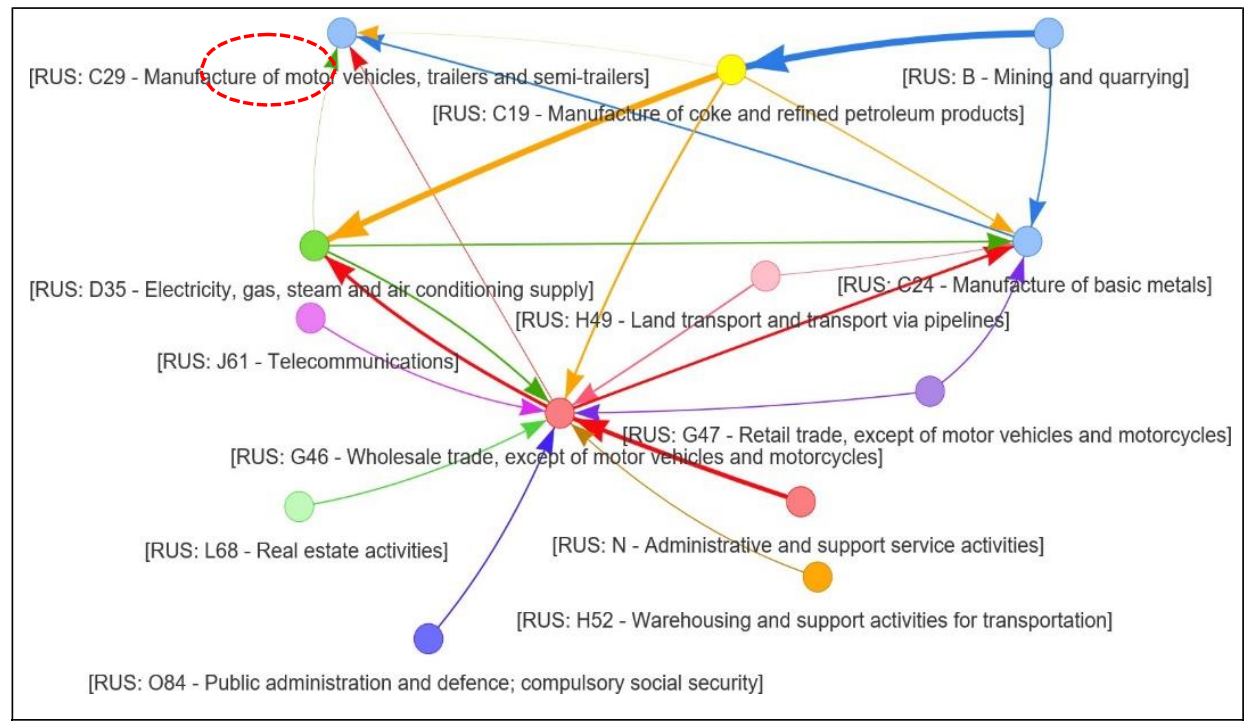

Fig.4. Basic suppliers of the Russian automotive industry

Source: authors

Cluster development in the automotive industry is just originating. It consists mostly in stimulating cluster development by the government - by funding the activity of managing companies being in the cluster of the Ministry of Economic Development and subsidizing joint industrial cooperation cluster projects implemented by the Ministry of Industry and Trade. Clusters are targeted toward development of local subcontracting, mainly for the private sector conformity with regulatory requirements of global companies regarding the cooperation with Russian component vendors for passenger car assembly. We also note technological uniformity of products, selection of cluster participants and suppliers for their inclusion into the global supply chain by geographical priority. These processes mean mainly the appearance of industrial cooperation among Russian industrial companies rather than cluster development. Today, the most common tools of cluster development cover programs for carrier progression and additional education for managers and engineers; targeted investment projects performed by large foreign and Russian companies to increase localization and production process upgrade, government orders for the defence industry.

Secondly, let stress the low involvement of universities and R\&D institutions into the activity of cluster facilities, small amount of small companies engaged in manufacturing high-tech products and actual absence of industrial (applied) venture capital. Passivity of these components does not allow to state, that an innovative ecosystem was built in the automotive industry. This fact confirms once again the assertion about just nascent industrial cooperation rather than cluster development [18].

Thirdly, there is a contradicting regulatory environment. 
Table 1. Regulatory environment for the cluster policy

\begin{tabular}{|l|l|}
\hline Law & Comment \\
\hline $\begin{array}{l}\text { On Industrial Policy in the Russian } \\
\text { Federation (Federal Law as of December 31, } \\
\text { 2014, Ref. No. 488-Ф3) }\end{array}$ & $\begin{array}{l}\text { The emphasis is made on managing } \\
\text { responsible ministries and agencies rather } \\
\text { than on contract conclusion between industrial } \\
\text { companies. The law does } \\
\text { not revoke the need to apply other laws. }\end{array}$ \\
\hline
\end{tabular}

Rules for the Subsidies Distribution and The emphasis is made on the document Granting from the Federal Budget to "Development program" having no legal force Budgets of the RF Constituent Entitiesto and clear responsibility for financial results. Implement Measures Foreseen by Expansion Plans for Pilot Innovative Territorial Clusters(Decree of the RF Government as of March 6, 2013, Ref. No. 188)

On Industrial Clusters and Specialized The emphasis is made on the reporting rules Organizations of Industrial Clusters (Decree of specialized entities to authorities. The basis of the RF Government as of May 31, 2015,for uncontrolled lobbyism of individual Ref. No. 779) private interests.

On Approval the Rules for Granting The emphasis is made on cluster projects Subsidies from the Federal Budget to the rather than cluster development. NonIndustrial Cluster Participants to Reimbursetransparent project selection procedures, a Part of Costs when Implementing Jointfinancial support only. No responsibility for Production Projects for the Importthe result.

Substitution (Decree of the RF Government as of January 28, 2016, Ref. No. 41)

Source: Implementable laws often duplicate existing ones creating additional contradictions and vague exceptions to the rules. For example, Part 6 of Article 78 of the Russian Federation Budgetary Code contains ready regulations for co- financing and co-management by different owners; however, there is a criminal penalty according to Article 178 of the Criminal Code for cooperative interaction as for restricting competition. Insufficiency and relevancy of judicial practice in these areas create additional costs for concluding contracts.

\section{Discussions}

Currently, Russian institutions cannot operate as a guide of changes, which means the impossibility to implement a full- featured cluster policy within the whole national economy. The current economic structure is inert and conceives innovations very poor [23].

Transformation experience in the automotive industry, perhaps, is the most relevant and indicative. It became possible to solve initiation problems and implement changes only after systemic implementation of international management practices at Russian industrial facilities, improvement of federal and regional laws by the government in cooperation with foreign investors [24-25]. Creation and implementation of the market economy fundamental institutions with transparent contracts between change stakeholders has opened the possibility for economic entities to transform independently, without the governmental impact.

Provision of the Russian automotive industry with a global scale of operations has played a positive role, but the standing behind in technological development becomes stable [2627]. Therefore, implementation of the full-featured cluster policy is the urgent task today this is the only way to integrate the national economy into global value chains at the higher 
technological conversion level.

\section{References}

1. C. Jona-Lasinio, S. Manzocchi, V. Meliciani. Knowledge based capital and value creation in global supply chains. Technological Forecasting and Social Change, Available at: https://www.scopus.com/ (2019)

2. M. Sigala, Mass customisation implementation models and customer value in mobile phones services: Preliminary findings from greece. Managing Service Quality, 16(4), 395-420 (2006)

3. M. Gancarczyk, J. Gancarczyk, J. Bohatkiewicz, SME roles in modular value chains: Perspectives for growth and innovativeness. Entrepreneurial Business and Economics Review, 5(3), 95-117 (2017)

4. K. Choi, R.-.B. Jean, D. Kim. The impacts of organizational learning capacities on relationship-specific innovations: Evidence from the global buyer-supplier relationship. International Marketing Review, 36(6), 1042-1066. (2019)

5. B. Davis-sramek, A. Omar, R. Germain. Leveraging supply chain orientation for global supplier responsiveness: The impact of institutional distance. International Journal of Logistics Management, 30(1), 39-56. (2019)

6. R. Strange, J. Humphrey, What lies between market and hierarchy? Insights from internalization theory and global value chain theory. Journal of International Business Studies, Available at: https://www.researchgate.net/ (2018)

7. C. Beverelli, V. Stolzenburg, R.B. Koopman, S. Neumueller. Domestic value chains as stepping stones to global value chain integration. World Economy, 42(5), 1467-1494 (2019)

8. O. Karasev, A.V. Beloshitsky, S.S. Trostyansky, and A.O. Krivtsova. National innovation systems: A case study of the leading developing countries. European Research Studies Journal, 21, 713-723. 2 (2018)

9. H. Graf, M. Kalthaus. International research networks: Determinants of country embeddedness. Research Policy, 47(7), 1198-1214 (2018)

10. A. Messenni Petruzzelli, G. Murgia, 2019. University-Industry collaborations and international knowledge spillovers: a joint-patent investigation. Journal of Technology Transfer, Available at: https://www.scopus.com/ (2019)

11. M. Johansson, M. Karreman, A. Foukaki. Research and development resources, coopetitive performance and cooperation: The case of standardization in 3GPP, 20042013. Technovation, [online], Available at: https://www.scopus.com/ (2019)

12. H. Etzkowitz, E. Germain-Alamartine, J. Keel, C. Kumar, K. N. Smith, E. Albats, Entrepreneurial university dynamics: Structured ambivalence, relative deprivation and institution-formation in the Stanford innovation system. Technological Forecasting and Social Change, 141, 159-171 (2019)

13. H. Etzkowitz, C. Zhou, Innovation incommensurability and the science park. $R$ and $D$ Management, 48(1), 73-87 (2018)

14. N. Budylina. Entrepreneurial universities and regional contribution. International Entrepreneurship and Management Journal, 14(2), 265-277 (2018)

15. C. Champenois, H. Etzkowitz. From boundary line to boundary space: The creation of hybrid organizations as a Triple Helix micro-foundation. Technovation, 76-77, 28-39 (2018) 
16. Law searching system. Available at: http://www.consultant.ru/(application date 15.02.2019)

17. Eurasian Economic Commission. Department of Industrial Policy. Comprehensive analysis of the state and development of the automotive industry of the member states of the Eurasian Economic Union. Moscow, 2016.88p.

18. Federal Custom Service. Available at: http://www.customs.ru/ (2018)

19. Rosstat. Available at: https://www.fedstat.ru/(2018)

20. World Input-Output Database. Available at: http://www.wiod.org/database/wiots16 (2018)

21. AlmaGrid software. Available at: http://www.almagrid.com/ru/almaGRID_almaGRID_Software.htm (2018)

22. M. Nadanyiova, E. Kicova, The concept of BSC system in bus transport companies as a tool of modern management trends. In Globalization and its socio-economic consequences, Rajecke Teplice, Slovak republic, 477-484 (2015)

23. V. Spitsin, A. Mikhalchuk, N. Chistyakova, L. Spitsyna, I. Pavlova, Development of innovative industries in Russia under unfavourable external environment, Equilibrium. Quarterly Journal of Economics and Economic Policy 13, 467-485 (2018)

24. M. Malkina, Spatial wage inequality and its sectoral determinants: The case of modern Russia, Oeconomia Copernicana 10, 69-87 (2019)

25. D. Popescu Ljungholm, Autonomous car regulation in the smart transportation infrastructure: Ethical issues, legal liabilities, and privacy concerns, Geopolitics, History, and International Relations 11, 7-12 (2019)

26. C. Slaby, Decision-making self-driving car control algorithms: Intelligent transportation systems, sensing and computing technologies, and connected autonomous vehicles, Contemporary Readings in Law and Social Justice 11, 29-35 (2019)

27. C. Bolton, V. Machova, M. Kovacova, K. Valaskova, The power of human-machine collaboration: Artificial intelligence, business automation, and the smart economy, Economics, Management, and Financial Markets 13, 51-56 (2018) 